\title{
THE PRESENCE OF THE VIOLA CAIPIRA IN KILZA SETTI'S MISSA CAIÇARA: OBJECTIVE AND SUBJECTIVE ASPECTS
}

\section{A PRESENÇA DA VIOLA CAIPIRA NA MISSA CAIÇARA DE KILZA SETTI: ASPECTOS OBJETIVOS E SUBJETIVOS}

\author{
Eliana Monteiro da Silva \\ Universidade de São Paulo \\ ms.eliana@usp.br
}

\begin{abstract}
This article analyzes the Brazilian composer Kilza Setti's Missa Caiçara (Caiçara Mass), focusing on the fact that the viola caipira (peasant viola) was widely used in this piece, along with other instruments that are frequently employed in this musical genre. Some objective and subjective aspects of the compositional process of this piece are discussed here, as an attempt to clarify the technical and stylistic procedures used by the musician in her oeuvre. Among the objective aspects is the employment of specific musical elements typically found in the fishing communities' music. Two of them are strumming chords and rhythmic motives that derive from the Portuguese fandango. On a more subjective tone Kilza pays tribute to São Gonçalo by quoting tunes that were traditionally sang in folk festivities. São Conçalo is a saint who is worshipped by the fishing communities for protecting infertile married women and prostitutes. Due to the limited amount of publications on Kilza Setti's Missa Caiçara, the main sources used were: an interview with the composer, which occurred in 2016; Kilza's Doctoral research about the coastline communities' music; José Luiz Chamorro Ribalta's Masters Dissertation about Missa caiçara, and the score and recording of the piece itself.
\end{abstract}

Keywords: Viola Caipira; Missa Caiçara; Kilza Setti; Women Composers; Brazilian Music. 


\section{Resumo}

Este artigo analisa a Missa Caiçara da compositora brasileira Kilza Setti, enfocando sua escolha de incluir a viola caipira entre os instrumentos frequentemente utilizados neste gênero musical. São discutidos alguns aspectos objetivos e subjetivos do processo composicional da obra, com objetivo de esclarecer os procedimentos técnicos e estilísticos usados por sua autora. Entre os aspectos objetivos encontra-se o emprego de elementos musicais específicos encontrados na música das comunidades de pescadores, como acordes rasqueados da viola caipira e motivos rítmicos derivados do fandango português. Em caráter mais subjetivo Kilza presta homenagem a São Gonçalo, santo louvado pela comunidade pesqueira pela proteção a mulheres inférteis e prostitutas, citando uma melodia tradicionalmente cantada em suas festas. Devido à pequena quantidade de trabalhos existentes sobre a Missa Caiçara de Kilza Setti, as principais fontes utilizadas foram uma entrevista realizada com a compositora em 2016, sua pesquisa de Doutorado acerca da música das comunidades caiçaras e a Dissertação de Mestrado de José Luiz Chamorro Ribalta sobre a peça, além da partitura e gravação da música em questão.

Palavras-chave: Viola Caipira; Missa Caiçara; Kilza Setti; Mulheres Compositoras; Música Brasileira.

\section{List of Figures}

1. Kilza Setti's Missa Caiçara autograph

2. Kyrie, measures 18 to 23: lyrics are presented in Latin and in Portuguese

3. Kilza's autograph of the São Gonçalo's tune. Measures 1 to 7 show the rhythmic motive played by the viola

4. Missa Caiçara's Cloria, measures 3 to 9. Viola caipira's part quotes the standard tune of São Gonçalo

5. Cloria, measures 111 to 117. Choir repeats the motive played by the viola caipira 
6. Credo, measures 44 to 48. Violin, viola and box's scores

7. Sanctus, measures 61 to 67. Syncopated rhythm recalls Brazilian modinha

8. Tenor melodic line in Kyrie, measure 18

9. Agnus Dei, measures 1 to 5. Voices in canon recall Tenor's theme in Kyrie

10. Agnus Dei, measures 38 to 42. The instruments return announces a climax in the Coda

11. Theme of Credo in the climax moment of Agnus Dei, measures 64 to 66

12. Kilza's image of Brazilian São Conçalo

13. Cloria, measures 50 to 52. São Conçalo tune sang by sopranos and altos

14. Catalog of the II Festival de Música Sacra

15. Interior part of the catalog shows Kilza Setti's Missa Caiçara

In 1990, the Brazilian composer Kilza Setti was invited by the Peruibe's City Hall to create an oeuvre to be presented in the city. The Secretary of Culture Luís Augusto Milanesi, who knew about Kilza's Ethnological studies from previous decades, which were done in Brazil and abroad, suggested she compose a peasant mass.

Although the idea seemed interesting, Kilza's researches had not specifically addressed peasant communities' culture and music, but the ones of the inhabitants of São Paulo's coastline. Consequently, she decided to pay tribute to the Caiçara by creating a Mass devoted to them, which was received with enthusiasm by the Peruibe's City Hall.

Beyond the thankful feeling she nurtured for those people, Kilza saw in this enterprise an opportunity to call the public's attention to some urgent problems they were facing at that time, like the real estate speculation in the region, the threat against their customs and traditions and the danger of losing their propriety. By using traditional features of their music, such as melodies, rhythms and specific instruments (e.g. the 
viola caipiral), she intended to highlight the richness of their culture and the splendor of such heritage. In addition, the composer wanted to discuss the life of women in some remote areas of Brazil and review the way they have been oppressed by the patriarchal education and the rigid religious rules. She managed to problematize this issue by invoking São Conçalo and the popular tunes that were related to him in local festivities. Originally, this saint came from Portugal, but later on he started to be worshipped by the Caiçara for protecting prostitutes and infertile married women.

All the aforementioned issues pervaded Kilza's decisions on the compositional procedures of Missa Caiçara. This article aims at pointing out the objective and subjective aspects of those choices, clarifying some technical and stylistic features employed by the composer in her work.

The main sources used in this analysis were: an interview with the composer made in the first semester of 2016; the Masters research by José Luiz Chamorro Ribalta on Missa Caiçara²; Kilza's book entitled Ubatuba nos cantos das praias: estudo do caiçara paulista e de sua produção musical ${ }^{3}$; and the recording of the Missa Caiçara produced by Radio Cultura FM of São Paulo in 1996. The two scores of the mass, one being original and other one edited by Ribalta in his work, were also extensively used.

\footnotetext{
I There are many similarities among the peasant and the coastal cultures, which explains, for instance, the use of the viola caipira for the Caiçara. The more relevant differences are due to the native region of the immigrants who colonized such areas, in the Brazil colonial times.

2 The specific data of this work can be seen in the References section of this paper.

3 Beachy songs of Ubatuba: studies on the Caiçara from São Paulo and their musical production (Kilza's PhD).
} 


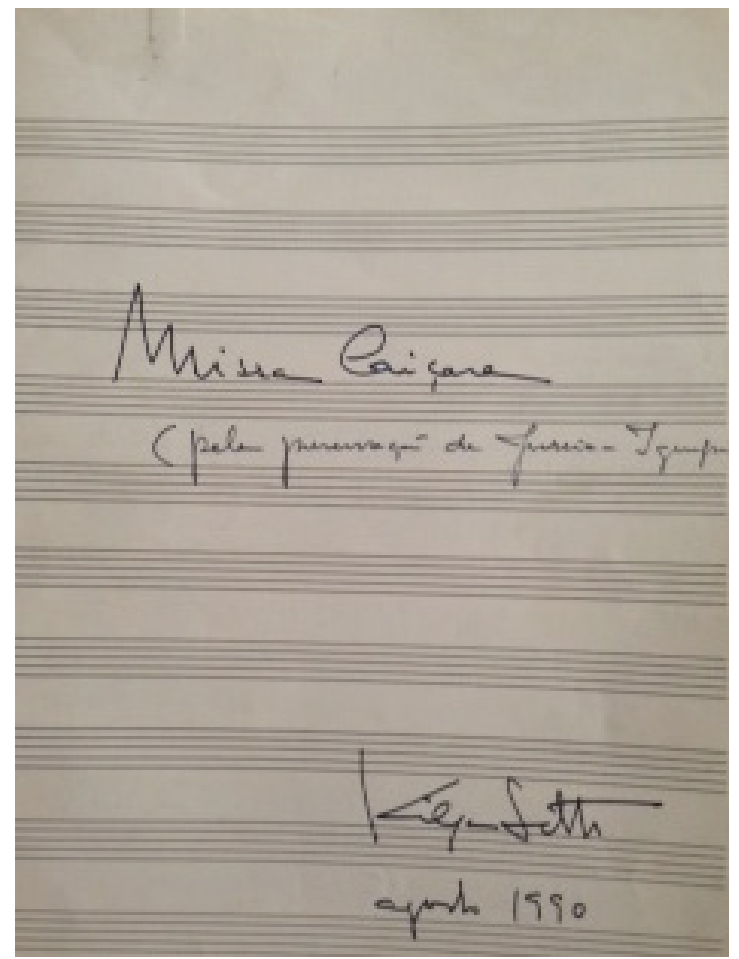

Figure 1 - Kilza Setti's Missa Caiçara autograph. Source: Kilza Setti's personal archive.

\section{Missa Caiçara: objective aspects of its compositional process}

In the present analysis, the musical elements are considered objective aspects of the compositional process. One of them is the fact that the traditional form of the mass, which was organized in parts, was kept intact. These parts were named Kyrie, Gloria, Credo, Sanctus, Benedictus and Agnus Dei. Kilza simultaneously used both Latin and Portuguese idioms for the singing parts, since she wanted the mass to be presented in theatres and churches 4 .

${ }^{4}$ According to the 1990's liturgics rules, the Church was not allowed to use texts in Latin, but in the official language of the country as to facilitate the understanding of the lyrics. However, in theaters, Latin was the common language used in musical performances. 
I began to sketch the main traits of each part as an attempt to structure them progressively. At some points I felt as if the religious ambience of traditional masses became more prominent; at others, like in Cloria or Credo, the Caiçara religious style prevailed (SETTI, 1990)5.

The orchestration kept the classical format, i.e., a vocal ensemble singing a capella. To establish a connection with the title Missa Caiçara, the composer decided to add violins, caixas ${ }^{6}$ and violas caipiras in the accompaniment of some parts, since they are typical instruments of the coastline villages. Usually a solo soprano voice is responsible for the lyrics in Portuguese, while the other voices sing in Latin. Kilza took advantage of both idioms' sonorities, offering a simultaneous translation from Latin to Portuguese to the audience. A Caiçara way of singing slow, melismatic and often repeating the last syllables - is indicated in almost the entire work. "[...] I proposed some free soloist singings, asking for glottis emissions and voices in a "tipe' manner - usual procedures of vocal Caiçara music" (ldem) ${ }^{8}$.

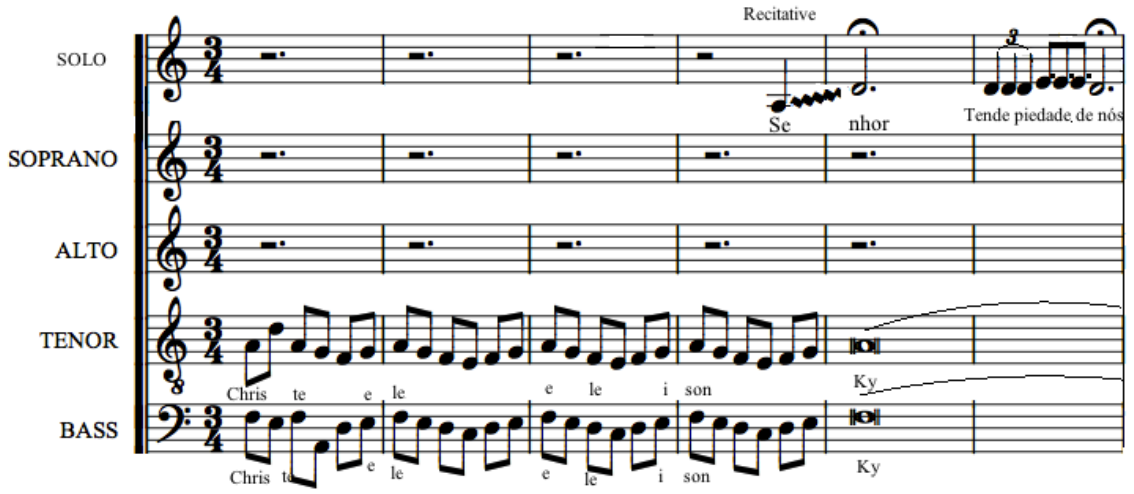

Figure 2 - Kyrie, measures 18 to 23: lyrics are presented in Latin and in Portuguese.

5 "Esbocei inicialmente os principais traços de cada uma das partes da missa e fui estruturando progressivamente cada parte. Em certos momentos transparece o clima liłúrgico das tradicionais missas; em outros, como no Clória e Credo, o estilo religioso caiçara predominou".

${ }^{6}$ The caixa (box) is a kind of drum.

7 The tipe is a way of singing with a very high-pitched voice.

8 "[...] propus alguns solos em canto livre, recomendando emissões de glote e vozes à maneira do "tipe"- procedimentos presentes à música vocal caiçara". 
The choir sings in all parts of the mass. Kilza dedicated special attention to some duets of sopranos, who sometimes sing separately of the group. The violas caipiras enter in the Cloria part, which is a little faster than the Kyrie'. They play rhythmic motives through acordes rasqueados (strumming chords), inspired in the old Portuguese fandango dance. Kilza quotes the viola's part of "a typically standard tune of the São Gonçalo sacred dance that is very popular in the coastline (SETTI, 1990)", which had been scored by her in 1966.

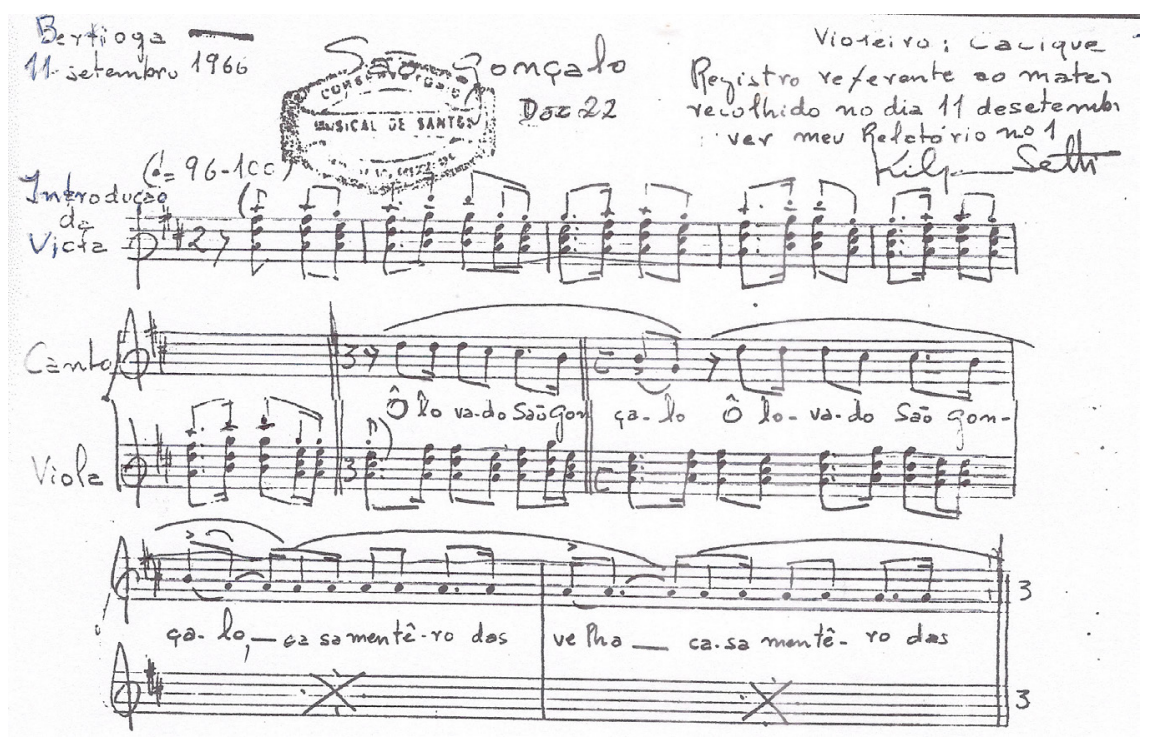

Figure 3 - Kilza's autograph of the São Gonçalo's tune.

Measures 1 to 7 show the rhythmic motive played by the viola.

Source: Kilza Setti's personal archive.

9 However, an introduction is made by the violas in the Radio Cultura's recording, where all the main themes of the mass are presented. Such an introduction was created by the interpreters in that very occasion, and approved by Kilza Setti. The introduction was not added to the score. 


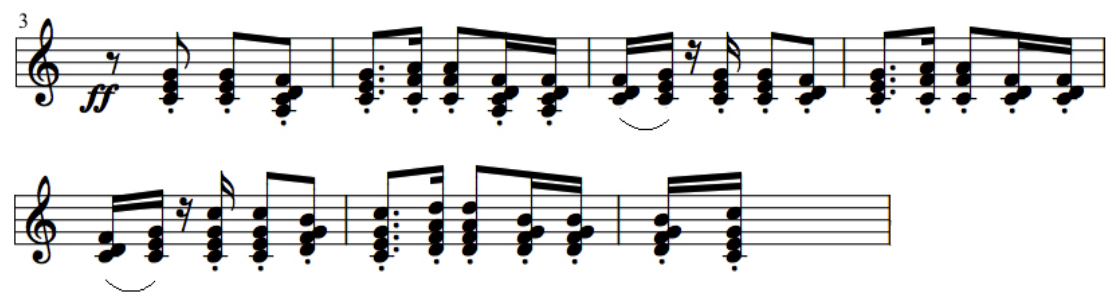

Figure 4 - Missa Caiçara's Gloria, measures 3 to 9.

Viola caipira's part quotes the standard tune of São Gonçalo.

The choir presents the same theme later, as can be viewed in the next figure.
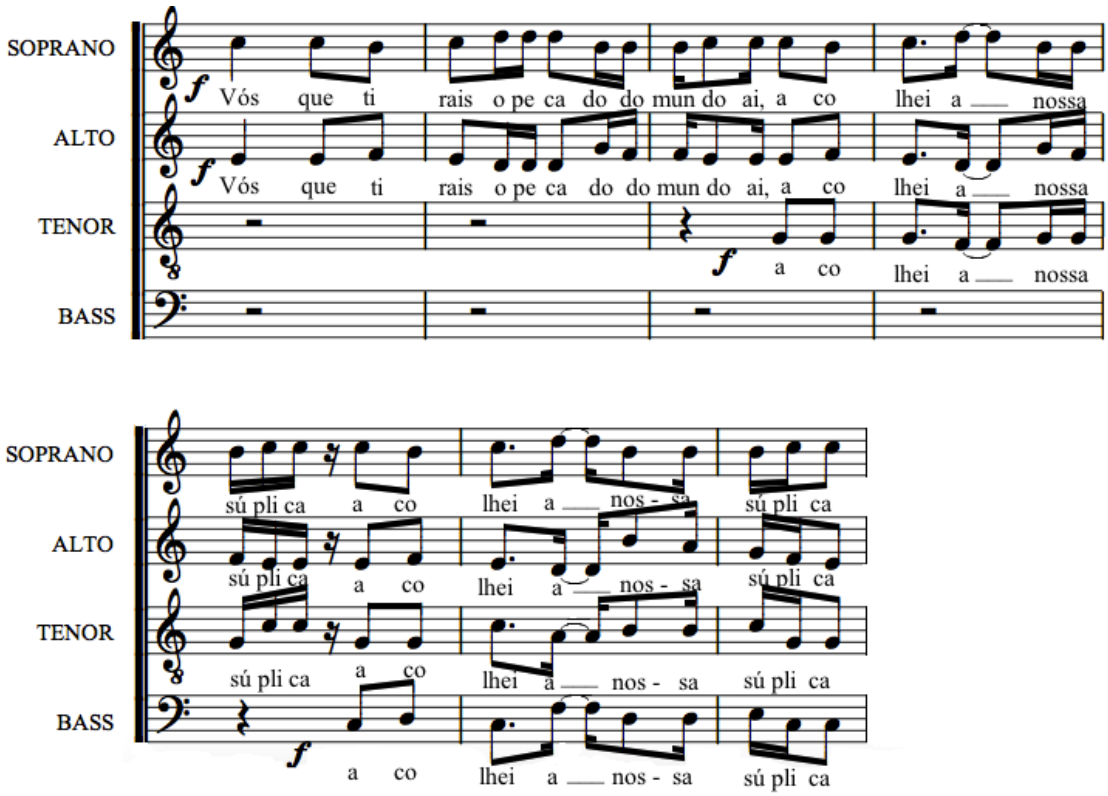

Figure 5 - Cloria, measures 111 to 117.

Choir repeats the motive played by the viola caipira. 
Kilza did not include arpeggio playing in the viola caipira scores. She said that the style was not used by the coastline people and she imagined the violas to be performed by them. In her words: "Referring to the 10 strings viola, I just used it in the reinforcing strumming chords, once the fingerstyle was rare in the Caiçara religious music" (Idem) 10 . She continued saying that "The original performance should stimulate the involvement of the coastline musicians (with no musical background) to accompany the Pervibe's choir"'!

In Credo, Kilza introduced two other instruments that were frequently used in the Caiçara music: the violin (or the rabeca), and the caixa. The melodic and rhythmic motives in this part is that of the xiba dance, also known as bate-pé. The violas caipiras play strummed chords, emphasizing the pulse and the tonality of $G$ Major'2.

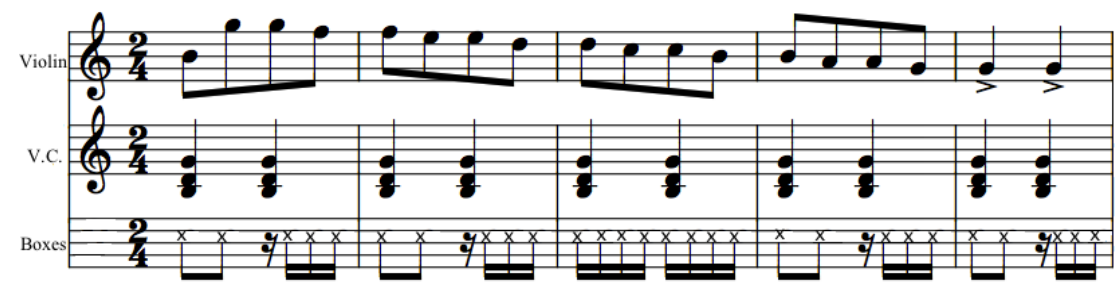

Figure 6 - Credo, measures 44 to 48. Violin, viola and box's scores.

Sanctus and Benedictus bring to the piece a completely different mood. They were conceived in a modal counterpoint, in order to create a contemplative ambience. There is no instrumental accompaniment in these parts, composed uniquely for a capella choir. According to Kilza, the Brazilian modinha style can be recalled in Sanctus, probably due to the syncopated rhythm of the soprano line, along with the Aeolian $\mathrm{G}$ sharp mode.

10 "Quanto à viola de 10 cordas, usei-a apenas nos rasgueados de reforço, uma vez que a forma ponteada é rara na música religiosa caiçara".

11 "A execução original previa o aproveitamento e participação de músicos das comunidades litorâneas (sem conhecimentos musicais) para acompanhar o coral de Peruibe".

12 G Major is a common tonality in xiba dances (SETTI, 1985, p. 107). 


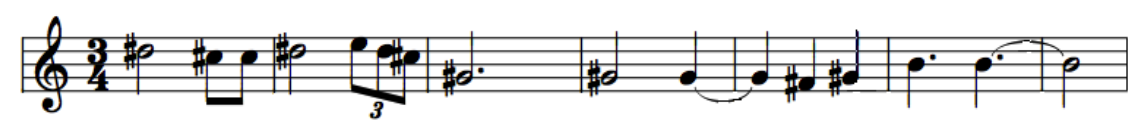

Figure 7 - Sanctus, measures 61 to 67. Syncopated rhythm recalls Brazilian modinha.

In order to finalize the mass, Agnus Dei joints all the voices, instruments and themes of the piece in a big Coda. Kilza starts with the choir in canon, remembering the melody sang by the tenor in the first part of Missa Caiçara, Kyrie. The fourth interval A/D is emphasized in Agnus Dei, both in the melodic line and between the voices in counterpoint.

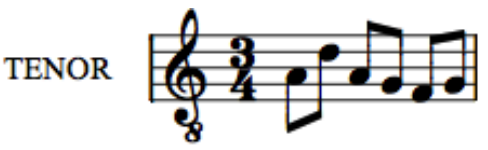

Figure 8 - Tenor melodic line in Kyrie, measure 18.

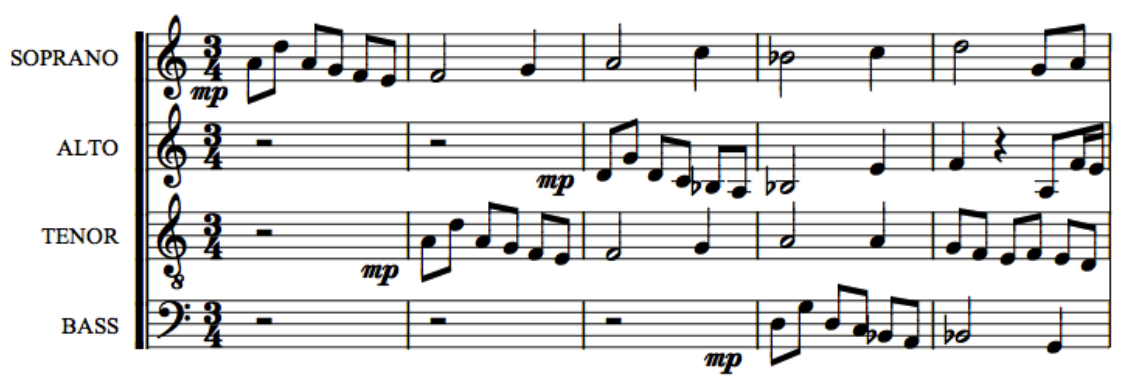

Figure 9 - Agnus Dei, measures I to 5. Voices in canon recall Tenor's theme in Kyrie.

The violas caipiras, violins and caixas enter in measure 42, after the soprano's phrase Agnus Dei donna nobis paccem, donna nobis paccem. The instruments' entrance prepares a climaxing point in the piece, where the themes of Credo and Kyrie are alternately sung by the choir. 


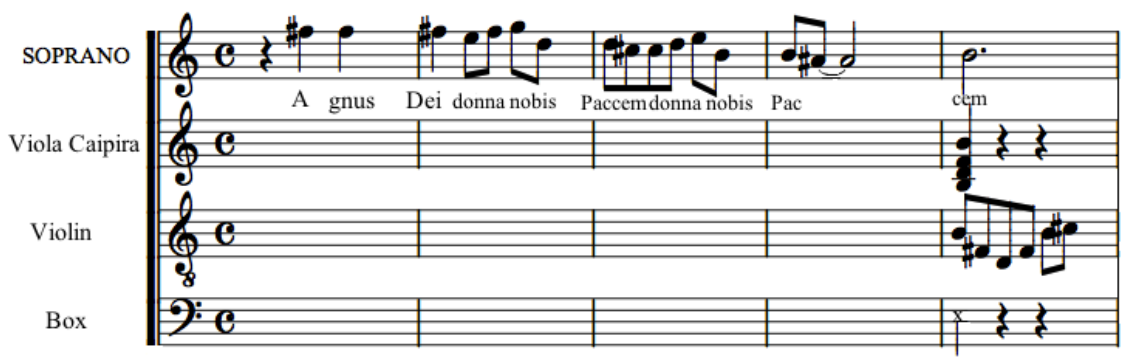

Figure 10 - Agnus Dei, measures 38 to 42.

The instruments return announces a climax in the Coda.

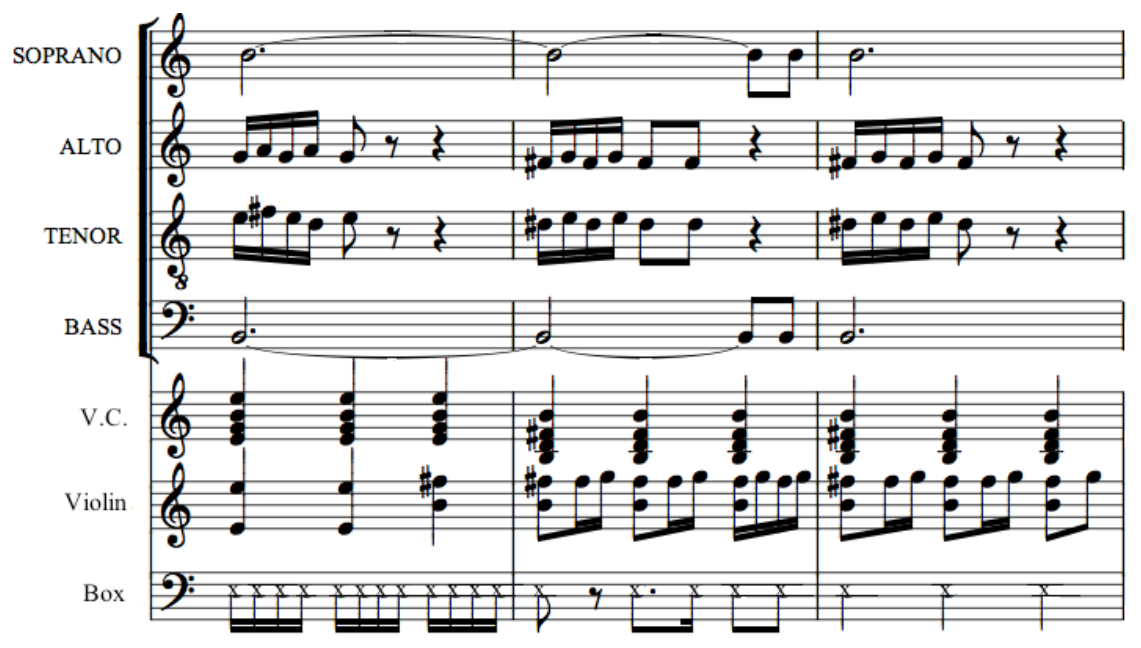

Figure 11 - Theme of Credo in the climax moment of Agnus Dei, measures 64 to 66. 


\section{Subjective aspects}

On a more subjective tone, Kilza brought the São Gonçalo memory to her Mass to discuss the women situation in some peripheral zones of Brazil, where they have been mostly oppressed by the patriarchal education and the rigid religious rules. The so-called Santo Violeiro (violist saint) is said to represent a protector of both prostitutes and infertile married women. The melody and rhythm of the São Conçalo sacred dance, practiced in festivities dedicated to him, would free these women's souls, giving them new lives and opportunities. According to Kilza, the originally Portuguese saint has been deeply worshiped for the Brazilian Caiçara, who had even created a national image of him playing the viola caipira.

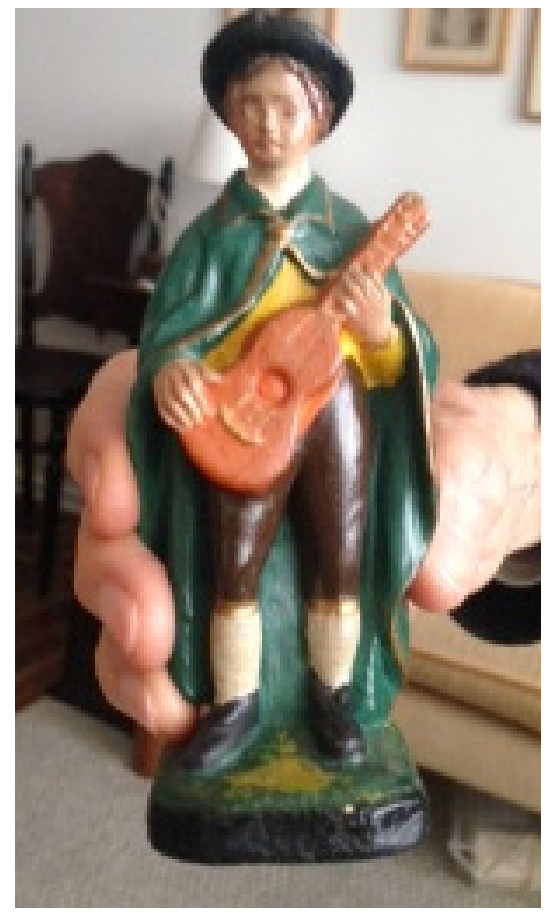

Figure 12 - Kilza's image of Brazilian São Gonçalo. Source: Kilza Setti's personal archive. 
The legend of São Conçalo came from Portugal. Before being sanctified, Gonçalo had been a bishop in Amarante. Portuguese tradition says that he used to dance over thumbtacks to sacrifice himself and dispose of his sins. He also called the prostitutes of the region to help them saving their souls through the rite.

"The therapist power of the dance employed by São Gonçalo to fight against the prostitution is known by every musician of Ubatuba" (SETTI, 1985, p. 112)13. Aside of this fact there is another version which attests that he answers to any prayer's supplication, mainly those related to women infertility. When studying in Portugal, to better understand the metropolitan influence in the Brazilian music, Kilza testified some practices adopted in parties dedicated to São Conçalo, like the manufacture of candies in phallic forms alluding to the saint's relations with sexual issues.

The Portuguese heritage present in the [Caiçara] worship to São Gonçalo is undeniable, as though as his relation with certain rites of fertility, through magic practices with phallic symbols and the superstitions related to the wedding (Ibid, p. 111$)^{14}$.

Nevertheless, the image of the saint with the viola caipira seems to be a Brazilian contribution. According to Kilza, the representation of the saint playing the instrument is completely unknown in the lberian Peninsula. One fisherman told her that "one person found him in the riverside with the viola in hands and asked: - Which saint is this? And a voice answered: - This is the São Conçalo [... ] He used to play the viola and sing" (Ibid, p. 112) 15 .

In her contact with the coastline communities, Kilza observed the oppressive situation of most of the women, both because of the strict

\footnotetext{
13 "A função da dança de São Conçalo, como prática terapêutica utilizada pelo santo para combater a prostituição das mulheres, é conhecida por todos os músicos de Ubatuba".

14 "É inegável a herança portuguesa do culto a São Gonçalo, bem como sua relação com certos ritos de fertilidade, mediante práticas mágicas com símbolos fálicos e de superstições relativas ao casamento".

15 "Dizem que foi um que achou ele na beira do rio, c'oa violinha na mão, então o que achou preguntou: - Que santo será esse? E uma voz respondeu: - Esse se chama o santo São Gonçalo [...] Ele tocava violinha e cantava". The incorrect words were quoted by Kilza Setti exactly as they were pronounced by the speaker.
} 
religious rules and for the imperative male chauvinism. Those who were married not only suffered with policies against birth control, but also with prejudice when infertile. The ones who happened to be single mothers could be banned from their families, sometimes falling in the prostitution field. Despite all these facts, Kilza observed their habit to sing all the time, either in sad or in happy situations. The São Conçalo benevolence towards these women represented an enormous relief in their everyday life.

The great respect and sorority nurtured by the composer to these brave women explain the important role São Gonçalo melody and rhythm play in the Missa Caiçara. Kilza understood that the sacred and supernatural symbols took part in their very conception of the reality.

For the Caiçara it is neither important to merge ordinary facts with holy issues nor keeping the miracles' power to serious situations. He claims for the supernatural all the time he faces difficulties or when the solutions seem to be hard to achieve, once he not only blends natural and supernatural, but also perceives them as a complementary process (SETTI, 1985, p. 235)'16.

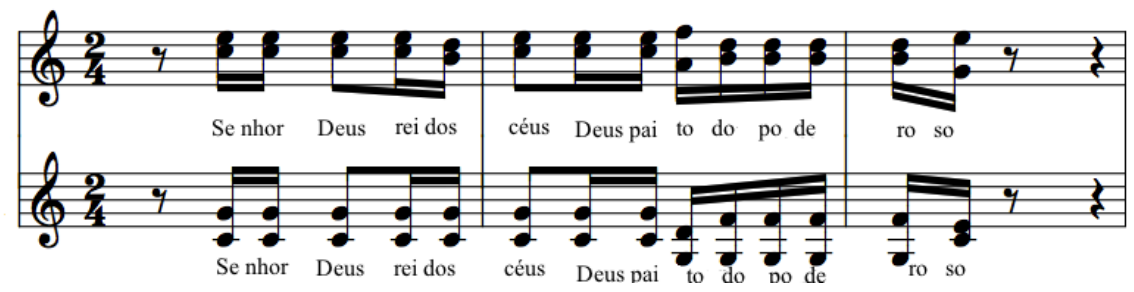

Figure 13 - Cloria, measures 50 to 52. São Gonçalo tune sang by sopranos and altos.

\footnotetext{
16 "Para o caiçara não importa misturar, ao sagrado, fatos corriqueiros, nem sequer reservar os poderes do milagre para situações mais graves. Utiliza o sobrenatural sempre que está em dificuldades ou sempre que as soluçōes se configurem como difíceis, uma vez que ele não separa o sobrenatural do natural, mas antes os vê num processo de intercomplementação".
} 


\section{The Missa Caiçara debut and recording}

Kilza Setti's Missa Caiçara was first presented in the $16^{\text {th }}$ of June, 1996. It took place in the Santuário Nossa Senhora de Fátima (Our Lady of Fatima's Sanctuary), during the II Festival de Música Sacra (II Sacred Music Festival) realized in the city of São Paulo. The Paulistano choir was conducted by Samuel Kerr, having as soloist singers Silvia Tessuto, Graziela Sanches, Rosemeire Moreira, Magda Paino, Nelson Campacci and Jean Szot. On the violas caipiras there were Gualtieri Beloni and Fernando Deghi, who created an introduction made by the violas for the debut. No member of the São Paulo coastline communities took part in that performance. The Radio Cultura FM of São Paulo recorded and produced a CD, which was used as audio reference in this article.

Why did not the fishermen's community participate in the mass presentation? Kilza explained that, although she tried not to adopt a complex structure and musical language, the local musicians found it difficult to realize the interpretation. The instrumental parts were easy for them, but the same could not be said about the vocal ones. In addition, operational problems and practical reasons related to the rehearsals revealed it would be easier to have the performance made by professional musicians, residents in São Paulo (SETTI, apud DEGHI, 200 1, passim). After some attempts in 1990 the score was abandoned, until the opportunity of being debuted in the II Festival de Música Sacra. 


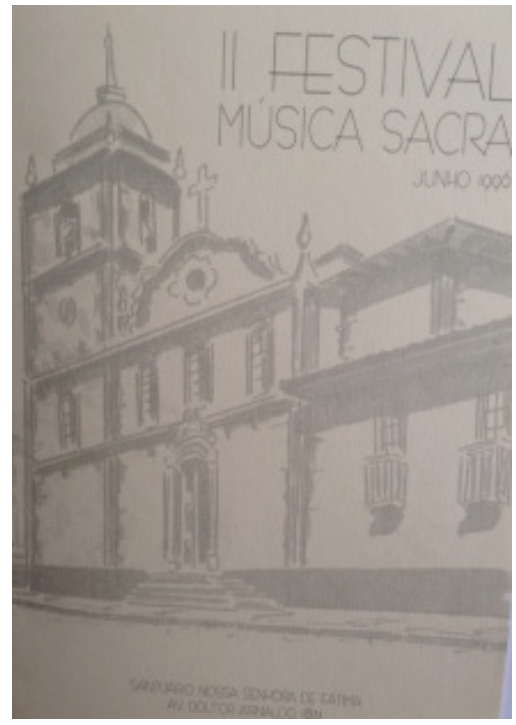

Figure 14 - Catalog of the II Festival de Música Sacra. Source: Kilza Setti's personal archive.

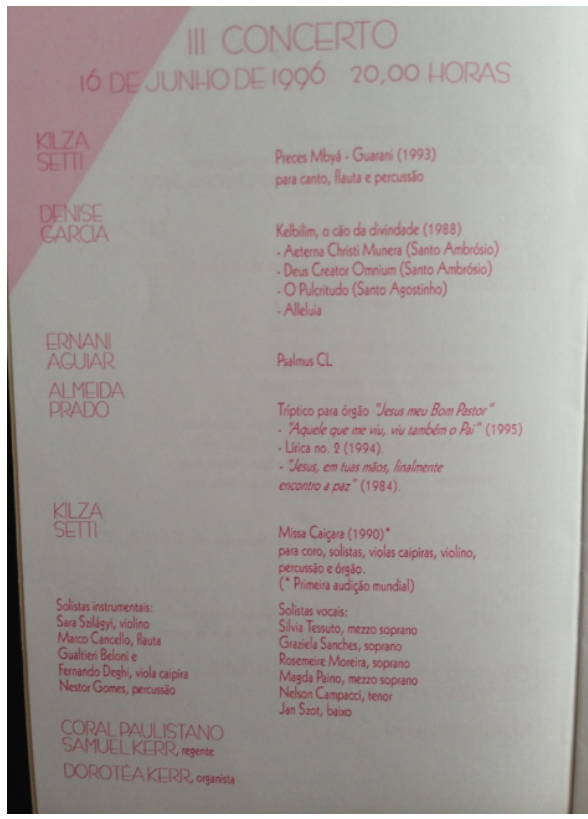

Figure 15 - Interior part of the catalog shows Kilza Setti's Missa Caiçara. Source: Kilza Setti's personal archive. 


\section{Final considerations}

This article brought some objective and subjective aspects of Kilza Setti's mass to show the composer's interest not only in sharing the information she acquired in her Ethnomusicologist studies among the coastline communities of São Paulo, but also in perpetuating it through the invention of a beautiful musical oeuvre. In Missa Caiçara, Kilza expressed her feelings about different issues, beginning with the respect for some traditional musical forms like the mass, passing by the admiration for other cultures sometimes underestimated in the academic music field, as the Caiçara, and ending by a discussion about the women's situation in some peripheral zones, such as the São Paulo's coastline. She manages to do it with excellence and to call attention to some instruments like the viola caipira, hardly used in the classical music repertoire.

Despite the complexity, creativity and information contained in the Kilza Setti's Missa Caiçara, the oeuvre had just two performances realized and one recording made publicly available. Unfortunately, it is a common data regarding women composers' production in this field.

Therefore, this article intends to give Kilza Setti and other women's music more visibility, not only in the Brazilian territory but also abroad.

\section{References}

DECHI, Fernando. Viola Brasileira e suas possibilidades. São Bernardo do Campo, Violeiro Andante Editora, 2001.

MOREIRA, Rosemeire. A estilística como subsídio para análise poéticomusical e sugestões interpretativas em três canções de Kilza Setti. 2014. Masters Dissertation (Music). University of São Paulo, São Paulo.

RIBALTA, José Luiz Chamorro. Missa Caiçara: uma abordagem analíticointerpretativa da obra de Kilza Setti. 2011 . Masters Dissertation (Music). University of São Paulo, São Paulo.

SETTI, Kilza. Notas sobre a Missa Caiçara para CD. São Paulo, 1990, Unpublished. 
Notas sobre a produção musical caiçara: música como foco de resistência entre os Pescadores do litoral paulista. 1997. PhD Thesis (Social Anthropology) Instituto de Estudos Brasileiros, USP, São Paulo.

Kilza Setti (CD). Live recording produced by Radio Cultura FM. São Paulo, 1996.

Ubatuba nos cantos das praias: estudo do caiçara paulista e de sua produção musical. São Paulo, Editora Ática, 1985.

Autograph of São Conçalo's tune. Bertioga, 1960.

Interview conceded to Eliana Monteiro da Silva. São Paulo, 2016, Unpublished.

\section{Author Data}

Eliana Monteiro da Silva is a pianist, professor and music researcher. Her studies address the musical production of women composers, which she also makes available through concerts and recordings. She is author of the book "Clara Schumann: compositora $x$ mulher de compositor" (Clara Schumann: Composer x composer's wife), published in 2011, and of the CD "Clara Schumann - lieder e piano solo", recorded in 2012. PhD in Music, she develops a postdoctoral work at the University of São Paulo, focusing on the Latin American women composers' music. She is one of the founder members of Sonora (www.sonora.me) and Polymnia (www.polymnia.webnode.com) groups, both related to women composers' issues. Since 2010 she keeps the Duo Ouvir Estrelas with the singer Clarissa Cabral, which was responsible for the first Brazilian recordings of some Clara Schumann's songs.

Recebido em: 06/09/2016 Aprovado em: 09/12/2016 